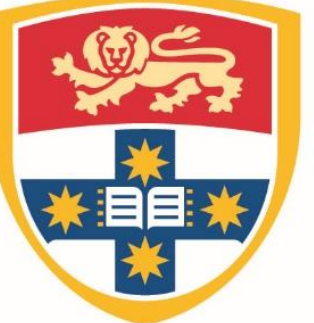

\title{
THE UNIVERSITY OF
}

SYDNEY

Economics Working Paper Series

$$
2015-12
$$

Incomplete Credit Markets and Monetary Policy

\author{
Costas Azariadis, James Bullard, \\ Aarti Singh \& Jacek Suda
}

May 2015

(This version February 2017) 


\title{
INCOMPLETE CREDIT MARKETS AND MONETARY POLICY
}

\section{Costas Azariadis* ${ }^{*}$ James Bullard ${ }^{\dagger} \quad$ Aarti Singh $^{\ddagger}$ Jacek Suda ${ }^{\S}$}

This version: 17 February 2016

\begin{abstract}
We study monetary policy when private credit markets are incomplete. The macroeconomy we study has a large private credit market, in which participant households use non-state contingent nominal contracts (NSCNC). A second, small group of households only uses cash and cannot participate in the credit market. The monetary authority supplies currency to cash-using households in a way that changes the price level to provide for optimal risk-sharing in the private credit market and thus to overcome the NSCNC friction. For certain large negative aggregate shocks the zero lower bound on nominal interest rates may threaten to bind. A temporary price level intervention by the monetary authority ensures a smoothly functioning (complete) credit market. The monetary policy studied in this model can be broadly viewed as a version of nominal GDP targeting.

Keywords: Monetary policy, incomplete credit markets, non-state contingent nominal contracts, life cycle economies, heterogeneous households, nominal GDP targeting. JEL codes: E4, E5.
\end{abstract}

*Washington University in St. Louis, and Federal Reserve Bank of St. Louis.

${ }^{\dagger}$ Federal Reserve Bank of St. Louis. Any views expressed are those of the authors and do not necessarily reflect the views of others on the Federal Open Market Committee.

$\ddagger$ University of Sydney.

$\S$ Narodowy Bank Polski. Any views expressed do not necessarily reflect the views of the Narodowy Bank Polski. 


\section{Introduction}

Following the financial crisis and recession of 2007-2009 in the U.S., policymakers have focussed on private credit markets and the interaction of households with these markets. ${ }^{1}$ This is because preceding the crisis, households presence in the private credit markets increased substantially. ${ }^{2}$ Very often, these financial transactions are in nominal terms. Typically, young households with mortgage debt are net nominal borrowers, and older households are net nominal lenders. Apart from being nominal, these contracts are usually not contingent on future income realizations. This market incompleteness of private credit markets is often ignored in the monetary policy analysis where nominal rigidity is in the form of prices set for a number of periods ahead, the nominal price rigidity models. In this paper we study how the non-state-contingent nominal contracting (NSCNC) friction in credit markets impacts the design of monetary policy and what kind of policy can ensure a smoothly operating credit market.

In recent times, the Federal Reserve faced an additional constraint while conducting monetary policy. The short-term nominal interest rate targeted by policymakers in the U.S. effectively hit the zero lower bound. In order to provide further policy accommodation subsequent to this event, the Federal Reserve embarked on two types of policies. One of these is popularly known as "forward guidance" - a promise by the central bank to hold interest rates at the zero lower bound beyond the time when the zero lower bound is

\footnotetext{
${ }^{1}$ This paper has benefitted from considerable input on earlier versions, many with a somewhat different focus than the current paper. The authors thank Patrick Kehoe, Jonathan Heathcote, Keith Kuester, Jose Dorich and comments by seminar and conference participants at the Texas Monetary Conference, Rice University, the Konstanz Seminar on Monetary Theory and Policy, the Swiss National Bank, the European Central Bank, the Bank of Finland, the Minneapolis, St. Louis, Philadelphia, and Chicago Federal Reserve Banks, Deakin University, University of Tasmania, University of Queensland, Narodowy Bank Polski, the Meetings of the Society for Economic Dynamics, Workshop of the Australasian Macroeconomics Society and the Summer Workshop on Money, Banking, Payments and Finance at the Chicago Fed.

${ }^{2}$ For example, Mian and Sufi (2011) document that the 1995 U.S. household debt-toincome ratio was about 1.15 , but that by 2005 , it was approximately 1.65 , a 43 percent increase.
} 
actually binding. The other is popularly known as "quantitative easing" outright purchases of both privately-issued and publicly-issued debt. ${ }^{3}$ Both of these types of monetary policy responses have been popular in several other large economies with policy rates constrained by the zero lower bound. In our model when sufficiently large and persistent negative aggregate shocks hit the economy, the zero lower bound on nominal interest rates may threaten to bind. We examine a monetary policy which ensures a smoothly operating credit market and also deal effectively with the zero lower bound problem.

\subsection{What we do}

We consider a simple and stylized $\mathrm{T}+1$-period general equilibrium life cycle model of movements in private debt levels, interest rates, and inflation. ${ }^{4}$ One-period, privately-issued household debt and currency are the only two assets. We divide the population into two groups, a large number of credit market participants (a.k.a., "credit users") and a small number of credit market non-participants (a.k.a., "cash users"). The credit market has an important friction: Debt contracts must be specified and paid off in nominal terms, and may not be written in state-contingent form. We call this the non-state contingent nominal contracting, or NSCNC, friction, and we will discuss it extensively in the main text. There is a stochastic income growth process - an aggregate shock. In particular, aggregate labor productivity growth follows a first-order autoregressive process.

Participant households supply one unit of labor inelastically in each pe-

\footnotetext{
${ }^{3}$ The literature on these two policies is already very extensive. Therefore, a complete summary is beyond the scope of this paper. To list a few, see for instance Eggertsson and Woodford (2006), Filardo and Hofmann (2014), Levin, Lopez-Salido, Nelson, and Yun (2010), and Cole (2015) for forward guidance. For theoretical analysis of quantitative easing see Williamson (2012, 2015), Curdia and Woodford (2010, 2011), Woodford (2012) among others and D'Amico and King (2011), Gagnon, Raskin, Remache, and Sack (2011), Hamilton and Wu (2012), Joyce, Lasaosa, Stevens, and Tong (2010), Krishnamurthy and Vissing-Jorgensen (2011), and Neely (2015) for empirical evidence on quantitative easing.

${ }^{4}$ We think it is quite useful to consider the quarterly frequency so that the model can be appropriately compared to results from other models. The interest rates in such a case will all have a three-month interepretation.
} 
riod, but their productivity varies over the life cycle. ${ }^{5}$ We study a stylized situation in which participant households' life cycle productivity endowment is exactly peaked in the middle period of the life cycle. The credit-using households will issue debt on net during the first portion of the life cycle and hold positive net assets during the second portion. ${ }^{6}$ These households sell their labor productivity units on an open market at the prevailing competitive per unit stochastic wage. The real rate of growth in wages is also the real rate of growth of output in this economy.

The relatively small group of credit market non-participants, the currency users, are precluded from the credit market altogether. Their productivity endowment profile is flat and intermittent, so that they can earn income only sporadically (facing the same stochastic wage per productivity unit as the participant households). These agents consume at times when income is unavailable. ${ }^{7}$ To smooth consumption, the non-participant households use currency issued by the central bank. The price level in the economy will be determined by the currency demand of this cash-using group, subject to the aggregate labor productivity shock. The central bank supplies currency to the economy's cash-using households and can effectively control the price level of the economy through this channel.

Critically, the credit market participants in this model who hold positive net assets - the "savers" - could in principle use either cash or credit. We will ensure that the debt issued by relatively young credit market participants will pay a higher real return and so the savers will prefer to hold this privatelyissued debt rather than the publicly-issued currency. This means the net nominal interest rate will be positive. We think of zero short-term nominal

\footnotetext{
${ }^{5}$ There is no idiosyncratic uncertainty - the only source of uncertainty is the aggregate shock.

${ }^{6}$ While the model is simple and abstract, much of the borrowing that occurs can be thought of as mortgage debt, intended to move the consumption of housing services earlier in the life cycle.

${ }^{7}$ This segment of society can be roughly viewed as the unbanked sector. Some estimates suggest that about 8 percent of US households are unbanked, and as many as 20 percent are underbanked (they have a bank account but use alternative financial services). See Burhouse and Osaki (2012).
} 
interest rates as indicating that the publicly-issued currency is competing directly in real rate of return against the privately-issued paper of relatively young households, distorting their ability to sell their paper at an appropriate price and leading to inefficient outcomes in the credit market. Policy will seek to avoid this situation and therefore keep nominal interest rates away from zero.

Because the credit market is so large relative to the cash-using contingent, we analyze the model as if the monetary policy is one that completes the credit market. ${ }^{8}$ We think of the policymaker as having a hierarchical mandate: (1) Provide for smoothly functioning (i.e., complete) credit markets - one might think of this as "financial stability," and (2) keep inflation relatively low by hitting an exogenously given inflation target (which for convenience we assume to be zero).

\subsection{Main findings}

The stationary equilibrium of this economy naturally generates substantial levels of privately-issued household debt relative to GDP. We first show that if credit market participants were allowed to use state-contingent contracts, a stationary equilibrium exists in which the real interest rate in the credit market fluctuates in tandem with the aggregate shock - that is, with the aggregate growth rate of the economy. ${ }^{9}$ The private credit market transforms the unequal income across participant cohorts alive at a date $t$ into perfectly equal consumption. Each credit market participant would, in effect, have an equity share in the income of the credit sector of the economy earned at date $t$. This is a first-best risk-sharing outcome for the credit sector of this economy under the homothetic preferences we have assumed.

With non-state contingent nominal contracting, credit market participant households will contract nominal amounts of credit with a fixed nominal interest rate one period in advance. We show that in this situation, the central

\footnotetext{
${ }^{8}$ We think of this large credit market assumption as analogous to the "cashless limit" assumption made in the sticky price literature. For a discussion, see Woodford (2003).

${ }^{9}$ In this sense the credit market sector of the economy is dynamically efficient.
} 
bank by appropriately setting the price level each period can provide the otherwise missing state-contingency through a counter-cyclical price level policy. In this circumstance, all cohorts alive at date $t$ will again consume exactly equal amounts, and the real interest rate will again equal the output growth rate each period. Participant households will again have an equity share in the income of the credit sector of the economy, and this again constitutes optimal risk-sharing for the private credit market. A monetary policy in this class will replicate the complete credit markets allocation from a risk-sharing perspective. We call this the complete credit markets policy. This complete credit markets policy also generates seigniorage revenue for the central bank which it transfers to the cash users. As a result, the consumption of cash users, which is lower than that of credit users, is also proportional to the income of the cash sector at date $t$.

The policy described above will work well for relatively small shockssmall enough that the net nominal rate of interest always remains positive. However, for certain shock realizations the net nominal interest rate required to implement the complete credit market policy may threaten to encounter the zero lower bound. We discuss a policy option the monetary authority can use in order to maintain complete credit markets. The policy intervention involves a promise to engineer an increase in the price level one period in the future sufficient to to keep the net nominal interest rate positive. This promise is sufficient to ensure that the net nominal interest rate remains positive and the complete credit market policy remains intact. ${ }^{10}$ As additional shocks hit the economy, the zero lower bound situation will eventually dissipate and special policy actions will prove temporary.

We conclude that in economies where the key friction is NSCNC and the net nominal interest rate threatens to encounter the zero lower bound, monetary policymakers could respond with a price level increase. We will discuss interpretations of the monetary policy in this paper as nominal GDP targeting in the main text.

\footnotetext{
${ }^{10}$ If the zero bound is encountered in subsequent periods, the same policy action has to be repeated.
} 


\subsection{Recent related literature}

Financial market incompleteness due to the NSCNC friction has a long history in discussions of monetary-fiscal policy interactions. Bohn (1988), for instance, presented a theory in which a government can use inflation to change the real value of the nominal government debt in response to shocks as a substitute for changing distortionary tax rates. Chari, Christiano, and Kehoe (1991), Chari and Kehoe (1999), Schmitt-Grohe and Uribe (2004), and Siu (2004) debated the extent of inflation volatility required to complete markets, coming to differing conclusions in models with and without sticky prices. In the current paper, we have flexible prices but no taxation, nominal government debt, or fiscal policy, and the inflation volatility required to complete credit markets is the same as the volatility of the real output growth rate.

Recent papers such as Koenig (2013), Sheedy (2014) and Garriga, Kydland, and Sustek (2015) however primarily focus on monetary policy alone in economies where the NSCNC friction plays a key role in private credit markets. ${ }^{11}$ See Sheedy (2014) for an extensive background on the NSCNC friction. Sheedy (2014) also considers a situation in which both sticky price and NSCNC frictions are present, and argues that the NSCNC friction is the more important of the two in a calibrated case. Koenig (2013) considers a two-period economy, but the mechanism used to achieve the complete credit markets outcome is similar to our paper. Garriga, Kydland, and Sustek (2013) consider the effect of the NSCNC in housing markets on equilibrium allocations. Their analysis is quantitative-theoretic with a given monetary policy. They find the non-state contingent nominal contracting friction can be quite significant, and suggest that the nature of mortgage contracting has important implications for the impact of monetary policy on the economy. Following this recent literature, we simply assume NSCNC. Relative to the literature, our main contribution is the conduct of monetary policy when the

\footnotetext{
${ }^{11}$ Bullard (2014) provides comments on the Sheedy paper and suggests that results may generalize to a class of models like the present one. Werning (2014) also comments on Sheedy and discusses the possible effects of idiosyncratic uncertainty. There is no idiosyncratic uncertainty in the present paper.
} 
zero lower bound on the net nominal interest rate threatens to bind.

In our model with incomplete private credit markets, when sufficiently large and persistent negative aggregate shocks hit the economy, the zero lower bound on nominal interest rates may threaten to bind. In Buera and Nicolini (2014), if the shock to the collateral constraint that causes the recession is sufficiently large, the equilibrium real interest rate becomes negative for several periods. Therefore like our paper, in their model the economy may hit the zero lower bound temporarily in their paper. The general equilibrium life cycle model we use has recently been used to analyze issues related to monetary policy and the zero lower bound by Eggertsson and Mehrotra (2014). Their model, like ours, takes advantage of the natural credit market that exists in the life cycle framework, and they use it to study deleveraging, debt dynamics, and issues related to the zero lower bound. They focus on sticky prices as the key friction, whereas we concentrate on NSCNC.

The present paper follows in a tradition of monetary theory that emphasizes asset market participation and non-participation. The superior rate of return that can be earned by asset market participant savers then generates a positive nominal interest rate in the economy, and risk sharing can be a key concern of policymakers. This literature includes Alvarez, Lucas, and Weber (2001) and Zervou (2013). The monetary features of models related to the one presented in this paper have been studied by Azariadis, Bullard, and Smith (2001) and Bullard and Smith (2003a, 2003b). ${ }^{12}$.

The paper is organized as follows. Sections 2 and 3 describe our basic model and introduce key benchmark economies. Section 4 analyzes the role of monetary policy when credit markets are incomplete but the economy is away from the zero lower bound. Section 5 studies monetary policy when the zero lower bound on the net nominal interest rate threatens to bind. Section 6 concludes.

\footnotetext{
${ }^{12}$ See also Gomis-Porqueras and Haro (2009).
} 


\section{Environment}

There are two agents in this economy: households and the monetary authority. Households are of two types, "participants" and "non-participants." We also refer to these two types as "credit users" and "cash users," respectively. ${ }^{13}$ Both participant and non-participant household cohorts are atomistic, identical, and have mass $(1-\omega)$ and $\omega$, where $0<\omega<1$. Households live in discrete time $T+1$ with $T>2$. To interpret this model as a quarterly model in which households begin economic life with zero assets in their early $20 s$ and continue until their $80 s, T+1$ could correspond to 241 periods. A new cohort of households enters the economy each period and there is no population growth. The economy continues into the infinite past, so that $-\infty<t<+\infty$. The only assets in the economy are nominal debt loans in the credit market and currency. Loan contracts are one period non state-contingent and expressed in nominal terms. We call this the non-state contingent nominal contracting friction, or NSCNC. ${ }^{14}$ Prices are flexible.

\section{$2.1 \quad$ Stochastic structure}

There is an exogenous real wage $w(t)$ which follows

$$
w(t+1)=\lambda(t, t+1) w(t)
$$

with $w(0)>0 .{ }^{15}$ The gross rate of real wage growth between any dates $t$ and $t+1, \lambda(t, t+1)$ follows a standard autoregressive process. In particular, $\lambda(t, t+1)$ is given by

$$
\lambda(t, t+1)=(1-\rho) \lambda+\rho \lambda(t-1, t)+\sigma \eta(t+1),
$$

\footnotetext{
${ }^{13}$ There are no borrowing constraints, and debt is always fully repaid. There is no role for collateral. For alternative theories that emphasize collateral and come to different conclusions, see Williamson (2015) and Araujo, Schommer, and Woodford (2015).

${ }^{14}$ In Sheedy (2014), debt contracts can have long maturities. See also Garriga, Kydland, and Sustek (2015).

${ }^{15}$ This assumption can also be thought of as a aggregate linear production technology in which one productivity unit produces one unit of the good, subject to a multiplicative productivity shock. Then $\lambda(t, t+1)$ is the growth in productivity between dates $t$ and $t+1$.
} 
where the unadorned $\lambda>1$ represents the average gross growth rate, $\rho \in$ $(0,1), \sigma>0$, and $\eta(t+1) \sim N(0,1)$. The actual realization of the wage growth is denoted by $\lambda^{r}(t, t+1)$.

\subsection{Participant household}

The productivity endowments of the credit market participant households are given by $e=\left\{e_{s}\right\}_{s=0}^{T}$. This notation means that each household entering the economy has productivity endowment $e_{0}$ in their first period of activity, $e_{1}$ in the second, and so on up to $e_{T}$. For example, for a 241 period model the endowment profile is

$$
e_{s}=f(s)=\mu_{0}+\mu_{1} s+\mu_{2} s^{2}+\mu_{3} s^{3}+\mu_{4} s^{4}
$$

such that $f(0)=0, f(60)=57 / 100, f(120)=1, f(180)=57 / 100$, and $f(240)=0$. Solving these five equations yields the values for $\mu_{i}, i=0, \ldots, 4$. This stylized endowment profile is displayed in Figure 1.

Credit market participant households supply their life-cycle productivity units inelastically at the competitive real wage $w(t)$ per efficiency unit. As a result, at any point in time, income varies considerably in this economy. The total real income in the credit sector at date $t$ is given by $w(t) \sum_{s=0}^{T} e_{s}$. The bulk of participant income is earned in the middle portion of life. Since we assume that the productivity profile is symmetric, in this economy there is an exact balance between the need for saving into relative old age and the need for borrowing in relative youth in the credit sector. Participant households borrow and lend using one period NSCNC debt contracts.

The timing protocol in the credit market is follows. At any period $t$, agents enter with one-period nominal contracts carrying an interest rate $R^{n}(t-1, t)$ that were based on the expected growth rate between period $t-1$ and $t$, that is, $E_{t-1}[\lambda(t-1, t)]$, as well as expected inflation between period $t-1$ and $t$. Nature moves first and draws a value of $\eta(t)$ implying a value of $\lambda^{r}(t-1, t)$, the productivity growth rate between date $t-1$ and date $t$. The monetary policymaker moves next and chooses a value for its monetary policy instrument. Given these choices, credit-using households 


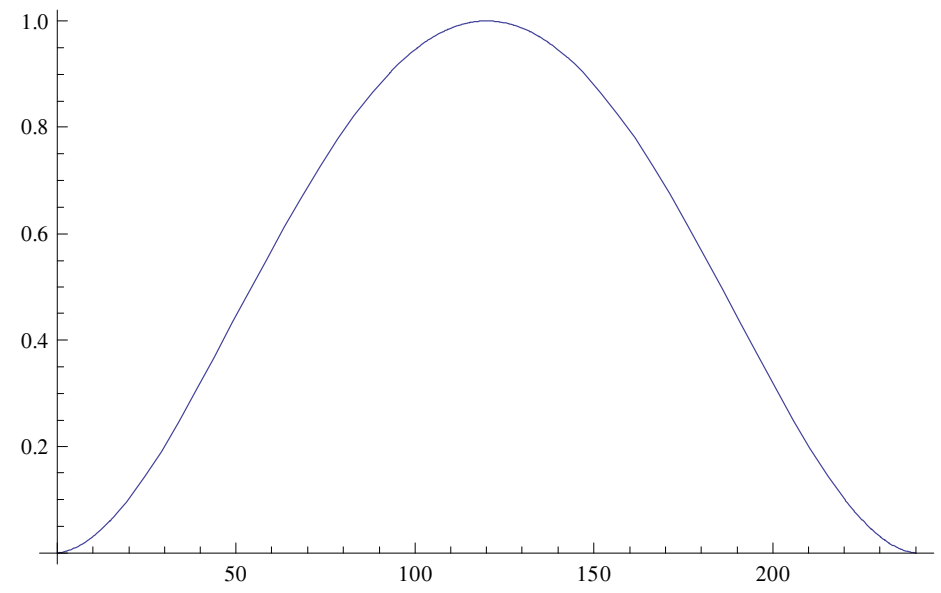

Figure 1: A schematic productivity endowment profile for credit market participant households. The profile is symmetric and peaks in the middle period of the lfe cycle. Total real income in the credit sector at date $t$ is this profile multiplied by $w(t)$. About 50 percent of the households earn 75 percent of the income in the credit sector.

make decisions to consume and save via non-state contingent nominal consumption loan contracts for the following period, carrying a nominal interest rate $R^{n}(t, t+1)$.

Let $c_{i}(t)$ denote the real value of consumption of the credit market participant cohort $i$ at date $t$. The cohort entering the economy at date $i=t$ maximizes expected utility ${ }^{16}$

$$
\max _{\{c\}} E_{t} \sum_{s=0}^{T} \ln c_{t}(t+s) .
$$

\footnotetext{
${ }^{16}$ In this formulation households do not discount the future. In life cycle economies, the discount factor does not have to be less than unity, and so to keep the analysis tractable, we assume that the discount factor equals one.
} 
subject to a sequence of budget constraints in real terms are expressed as

$$
\begin{aligned}
c_{t}(t) & \leq e_{0} w(t)-\frac{a_{t}(t)}{P(t)}, \\
c_{t}(t+1) & \leq e_{1} w(t+1)+R^{n}(t, t+1) \frac{a_{t}(t)}{P(t+1)}-\frac{a_{t}(t+1)}{P(t+1)}, \\
\cdots & \\
c_{t}(t+T) & \leq e_{T} w(t+T)+R^{n}(t+T-1, t+T) \frac{a_{t}(t+T-1)}{P(t+T-1)},
\end{aligned}
$$

where $R^{n}(t, t+1)$ is the one-period gross nominal rate of return on loans originated at date $t$ and maturing at date $t+1$ in the credit sector of the economy and $P(t)$ is the price level at date $t .{ }^{17}$ The net nominal loan amounts of the participant cohort $i$ at date $t$ is denoted by $a_{i}(t)$, and we interpret negative values as borrowing.

Note that in our model participants can hold both cash and credit. However the participant households holding positive assets ("savers") will not hold currency because the real rate of return on currency will be lower than or equal to the real rate of return on private debt in all states of the world in the stationary equilibria we study in this paper.

The standard consolidated budget constraint of the participant is therefore given by

$$
\begin{aligned}
c_{t}(t)+\frac{P(t+1)}{P(t)} \frac{c_{t}(t+1)}{R^{n}(t, t+1)} & c_{t}(t+T) \\
+\ldots+\frac{P(t+T)}{P(t)} \frac{R^{n}(t, t+1) \cdot \ldots \cdot R^{n}(t+T-1, t+T)}{P(t)} \frac{e_{1} w(t+1)}{R^{n}(t, t+1)} & \quad \leq e_{0} w(t)+\frac{P(t+1)}{P(t+T)} \frac{e_{T} w(t+T)}{R^{n}(t, t+1) \cdot \ldots \cdot R^{n}(t+T-1, t+T)}
\end{aligned}
$$

\footnotetext{
${ }^{17}$ We use the notational convention throughout this paper that $R$ represents gross real returns in the credit market and that other interest rates are differentiated by a superscript.
} 
Rewriting the right hand side of (8) as

$$
\begin{aligned}
\Xi_{t}(t)=e_{0} w(t) & +\frac{P(t+1)}{P(t)} \frac{e_{1} w(t+1)}{R^{n}(t, t+1)} \\
& +\ldots+\frac{P(t+T)}{P(t)} \frac{e_{T} w(t+T)}{R^{n}(t, t+1) \cdot \ldots \cdot R^{n}(t+T-1, t+T)} .
\end{aligned}
$$

From the participant households' optimization problem and by rearranging the Euler equation, the non-state contingent nominal interest rate, $R^{n}(t, t+1)$, is given by

$$
R^{n}(t, t+1)^{-1}=E_{t}\left[\frac{c_{t}(t)}{c_{t}(t+1)} \frac{P(t)}{P(t+1)}\right] .
$$

The $E_{t}$ operator indicates that households use information available as of the end of period $t$ before the realization of $\eta(t+1) \cdot{ }^{18}$ All cohorts have the same expectation of the aggregate growth rate, so that (10) suffices to determine the contract rate. For example, for agents entering the economy in any period $t-j$, the nominal contract will specify

$$
R^{n}(t, t+1)^{-1}=E_{t}\left[\frac{c_{t-j}(t)}{c_{t-j}(t+1)} \frac{P(t)}{P(t+1)}\right]
$$

The nominal interest rate depends jointly on the expected behavior of consumption as well as the expected policy rule for the price level.

\subsection{Non-participant household}

Non-participant households are precluded from the credit market. Like their participant agent counterparts, they live $T+1$ periods. Let the stage of life of cash users be denoted by $s=0,1, \ldots, T$. In $s=0$, these agents are inactive. They do no consume, nor do they earn labor income. In odd-dated stages of life, these agents have a productivity endowment $\gamma \in(0,1)$. We assume that $\gamma$ is fairly low - in addition, there is no life cycle aspect to the value of $\gamma$. By supplying labor inelastically, the households entering the economy at date $t$ earn income $\gamma w(t+s), s>0, s=1,3,5, \ldots, T-1$. In the even-dated stages of life, the non-participant households consume.

\footnotetext{
${ }^{18}$ For further discussion of this, see Chari and Kehoe (1999).
} 
The period utility for households born at date $t$ in these periods is $\ln c_{t}(t+s)$, $s=2,4,6, \ldots, T$. In each odd stage of life, these households solve a two-period problem, discounting all future two period problems to zero. ${ }^{19}$ Since the nonparticipant agents earn and consume in different periods, they save all income earned by holding currency, and then consuming everything before working again in the following period. ${ }^{20}$

The the real demand for currency at date $t$, denoted by $h^{d}(t)$, is therefore given by

$$
h^{d}(t)=\frac{\gamma T}{2} w(t) .
$$

Note that as the average gross real growth rate $\lambda>1$, their wages increase during their lifetime therefore these cash users do not carry currency beyond one period.

In this segement of the economy, at any date $t$ the even-dated cash users will use their cash and transfers from the central bank to buy consumption from the odd-dated cash users. This stylized design of the cash-using segment of the economy will deliver a conventional money demand, buffeted by the aggregate shock to productivity. The price level will be determined in this sector of the economy.

\subsection{The monetary authority}

The monetary authority (a.k.a., the central bank) views the large but incomplete private credit market as the primary focus of monetary policy. Policymakers have a hierarchical mandate, in which (1) The primary goal is to overcome the NSCNC friction in the credit market; and (2) A secondary goal is to hit an exogenously given inflation target on average, here taken to be zero for simplicity.

\footnotetext{
${ }^{19}$ For especially low values of $\lambda(t, t+1)$ these households may possibly wish to hold currency to aid consumption beyond the current even period into the next even periodbut, we assume they discount this possibility completely.

${ }^{20}$ This form of the two-period problem eliminates any steady state in which no agent wishes to hold currency.
} 
In our model, the monetary authority overcomes the NSCNC friction by influencing the value of the price level at each date $t$. How is it that the monetary policymaker can control the price level in this model? ${ }^{21}$ The policymaker supplies currency, $H(t)$, to the non-participant householdsthe cash users. The total real value of currency outstanding in the economy at date $t$ is given by $H(t) / P(t)$. We normalize the date 0 currency level to $H(0)=1$.

Equating the supply and demand in the currency market gives the following

$$
\frac{H(t)}{P(t)}=\frac{\gamma T}{2} w(t)
$$

The central bank chooses growth rate of currency between any two dates $t-1$ and $t, \theta(t-1, t)$, written as

$$
H(t)=\theta(t-1, t) H(t-1) .
$$

This implies

$$
\frac{\gamma T}{2} w(t) P(t)=\theta(t-1, t) \frac{\gamma T}{2} w(t-1) P(t-1)
$$

which can be written as

$$
\theta(t-1, t)=\frac{P(t)}{P(t-1)} \frac{w(t)}{w(t-1)} .
$$

From equation (16) it can been seen that at date $t, P(t-1)$ and $w(t-1)$ are known. The timing protocol for the economy means that nature moves first and chooses a growth rate $\lambda^{r}(t-1, t)$ and hence a value for $w(t)$. This means that the central bank, moving after nature, can choose the gross rate of currency creation $\theta(t-1, t)$ to set a value for $P(t)$. This choice of $P(t)$

\footnotetext{
${ }^{21}$ In this model the policymaker influences the price level without any control error, so that in effect the policymaker can simply choose the price level at each date. This aspect of the model is of course unrealistic, but the point here is to demonstrate what the optimal monetary policy would look like if such precise control were feasible. Keeping this type of assumption in place is akin to the analysis in the simplest versions of New Keynesian models in which shocks can be offset perfectly by the policymaker through appropriate adjustment of the nominal interest rate.
} 
is sufficient to characterize equilibrium in the cash-using sector of the economy. ${ }^{22}$ In this economy, at each date the seigniorage earned by the monetary policymaker is transferred to even-dated cash users.

There are some choices for $\theta$ that will turn out not to be optimal in this model, but which provide good benchmarks for comparison. The central bank could, for instance, choose $\theta(t-1, t)=1 \forall t$, in which case a fixed stock of currency would simply trade hands each period between odd-dated and evendated agents in the currency market. The price level would then fluctuate in response to shocks. We call this the fixed currency stock rule. Alternatively, the policymaker chooses $\theta$ in order to maintain $P(t)=P(t-1)=1 \forall t$ (or any other constant), where we normalize the date 0 price level $P(0)=1$. We will call this the price stability rule. The price stability rule is, broadly speaking, the type of policy advice that would stem from simple New Keynesian models assuming sticky prices. A variant of the price stability rule is that $\theta$ is chosen to produce a constant rate of increase in the price level. We will call this an inflation targeting rule. Note that the price stability rule is simply an inflation targeting rule in which the gross inflation target is equal to 1 , and the net inflation target is equal to zero.

\section{Stationary equilibrium}

Given the timing assumption, stationary equilibrium can be described as a sequence $\left\{R^{n}(t-1, t), P(t)\right\}_{t=-\infty}^{+\infty}$ in which households maximize utility subject to the constraints, markets clear, the monetary policymaker credibly adheres to a given rule which determines $P(t)$ and earns zero seigniorage. The economy continues into the infinite past, so that $-\infty<t<+\infty$. The date zero distribution of asset holdings is consistent with the stationary equilibrium under the proposed monetary policy.

The key condition for stationary equilibrium is that total asset holding

\footnotetext{
${ }^{22}$ The central bank's price rule will also determine the gross inflation rate in the economy and hence the gross real rate of return to currency holding, $R^{m}(t)$ at each date $t$ in the currency-holding portion of the economy.
} 
in the credit sector must sum to zero at each date $t$. This means

$$
\frac{A(t)}{P(t)}=\frac{a_{t-T+1}(t)+\ldots+a_{t-1}(t)+a_{t}(t)}{P(t)}=0
$$

where $A(t)$ is aggregate nominal asset holding. Note that the equation (17) can be written as an expression in expected real wages, nominal interest rates, and price levels along with the given distribution of asset holdings coming into the period.

\subsection{The non-stochastic balanced growth path}

An important benchmark in this economy is the non-stochastic balanced growth path. Let $\sigma=0$. In addition assume that the policymaker chooses the price stability rule $P(t)=P(t-1)=1 \forall t$ in order to achieve an exogenously given net inflation target of zero.

We conjecture that the gross real interest rate along the balanced growth path is $R=\lambda$. Since $w(0)=1$, then $w(t)=\lambda^{t} w(0)=\lambda^{t}$. When $R=\lambda$, equation (9) simplifies to $\Xi_{t}(t)=w(t) \sum_{i=0}^{T} e_{i}$. This the total real income earned in the credit sector of the economy at date $t$. This means that the household entering the economy at date $t$ chooses to consume $(1 /(T+1)) w(t) \sum_{i=0}^{T} e_{i}$. All other households alive at date $t$ will also choose to consume this amount. The consumption across the $T+1$ households exhausts total income in the credit sector. As a result the sum of asset holding across these households is zero. Therefore $R=\lambda$ is the real interest rate in the non-stochastic balanced growth path of the economy.

Figure 2 shows asset holding by cohort along the non-stochastic balanced growth path.

Figure 3 shows the level of household income by cohort and the level of consumption by cohort for this case. The private credit market completely solves the point-in-time (cross-sectional) income inequality problem for this economy.

Similar to Sheedy (2014), all credit sector cohorts choose to consume $(1 /(T+1)) w(t) \sum_{i=0}^{T} e_{i}$ and therefore have an "equity share" in the credit 


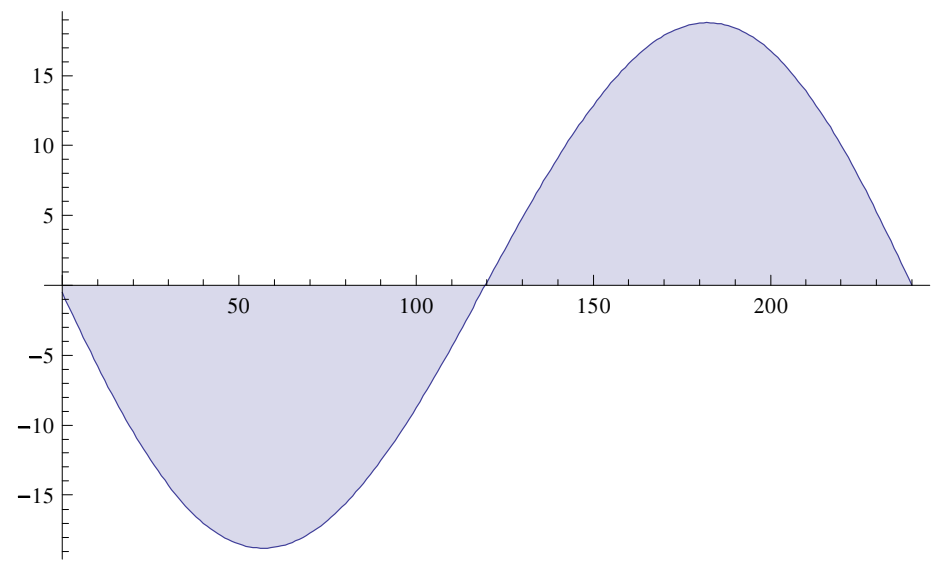

Figure 2: Net asset holding by cohort along the non-stochastic balanced growth path. Borrowing, the negative values to the left, peaks at stage 60 of the life cycle, roughly age 35, while positive assets peak at stage of life 120, roughly age 65 . About 25 percent of the population holds about 75 percent of the assets.

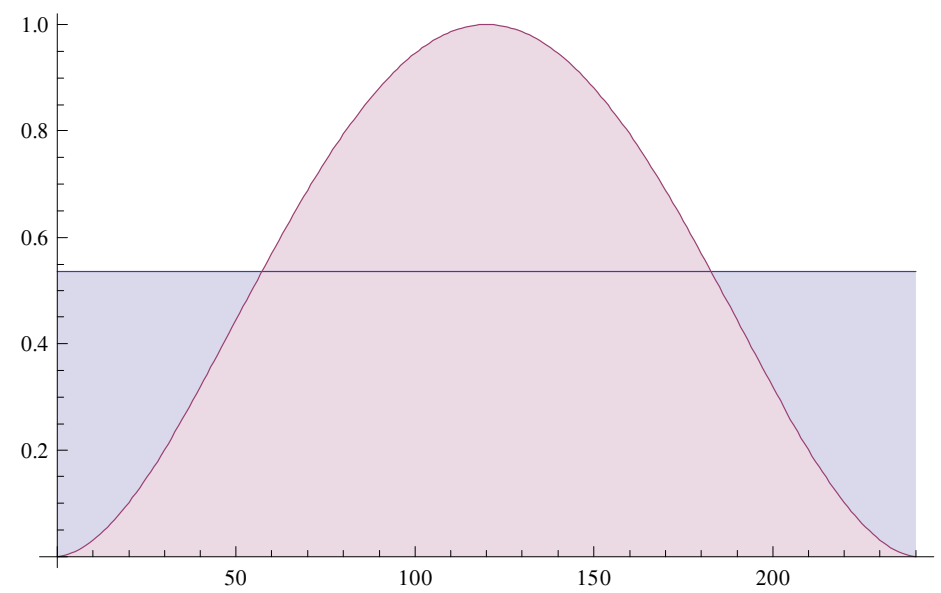

Figure 3: Schematic representation of consumption, the flat line, versus income, the bell shaped curve, by cohort along the non-stochastic balanced growth path with $w(t)=1$. The private credit market completely solves the point-in-time (cross-sectional) income inequality problem. 
sector of the economy - they split up the total available real income at date $t$ as equal real per capita consumption. Equity share contracts are optimal under the homothetic preferences we have assumed. Even though income at date $t$ is very different across households, the private credit market ensures that each household consumes an equal portion of the total real income in the credit sector - the private credit market completely solves the cross-sectional income inequality problem. In the next period, total real income in the credit sector will be higher by a factor $\lambda$, but this extra real income will also be split evenly among households alive in the next period.

What about the non-participant, cash-using households? Equation (16) indicates that given price stability, growth of currency $\theta=\lambda$, the gross nominal interest rate (10) $R^{n}=\lambda>1$, so the net nominal interest rate would always be positive. After seigniorage transfers, the consumption of even-dated cash users at date $t$ is therefore $\frac{\gamma T}{2} \lambda w(t-1)=\frac{\gamma T}{2} w(t)$.

\subsection{The stochastic complete markets economy}

We turn now to the stochastic case where we assume that $\omega \rightarrow 0$ for simplicity. In this limit, this implies that the economy has only credit market participants trading consumption loans.

We conjecture that the gross real interest rate $R(t, t+1), \forall t$, is always equal to the realized gross rate of wage growth $\lambda^{r}(t, t+1)$, in such a stationary equilibrium. Consideration of equation (9) indicates that, under this conjecture the right hand side of the budget constraint can be written as $w(t) \sum_{i=0}^{T} e_{i}$, that is, the constraint is linear in $w(t)$. Given the timing protocol of the model, $w(t)$ is known to households at date $t$ when optimization takes place. This means that households solve a non-stochastic problem under the conjecture at date $t$. The set of non-stochastic problems for the $\mathrm{T}+1$ households has a known solution, as shown in the last sub-section, namely that each household consumes $(1 /(T+1)) w(t) \sum_{i=0}^{T} e_{i}$, an "equity share" in the real output of the economy at date $t$. In addition, this solution implies $A(t)=0 \forall t$ and this verifies the conjectured stationary equilibrium.

What is the nature of this stationary equilibrium? Aggregate as well 
as individual consumption changes each period depending on the value of $w(t)$, but proportionately for all agents alive at that date. Accordingly, asset holding also rises and falls each period for each cohort at each date, but in proportion to the value of $w(t)$ at that date. The entire curve in Figure 2 , in other words, is multiplied by the realized value of $w(t)$. Along the nonstochastic balanced growth path, $w(t)$ would always increase by a factor $\lambda$. In the stochastic complete markets stationary equilibrium with state-contingent contracting, $w(t)$ follows the stochastic process given in equation (2). This provides a complete characterization of the asset-holding distribution in the economy at each date.

Versions of this complete markets stationary equilibrium with state-contingent contracting will be the target of the optimal monetary policy described in the remainder of the paper.

\section{Incomplete markets and monetary policy}

We now return to the full stochastic model. However, in this section we will assume that the zero lower bound is never encountered. We can think of this as a situation where $\sigma$ is positive but arbitrarily small, such that the probability of encountering the zero lower bound is extremely small. In the next section, we will allow for larger values of $\sigma$, and include encounters with the zero lower bound as part of the equilibrium. ${ }^{23}$

Can the monetary authority replicate the equity share consumption that characterizes the complete markets stationary equilibrium of the previous section? At each date $t$, the monetary policymaker moves after nature and chooses $P(t)$ such that

$$
\begin{aligned}
P(t) & =\frac{E_{t-1}[\lambda(t-1, t)]}{\lambda^{r}(t-1, t)} P(t-1) \\
& =\frac{(1-\rho) \lambda+\rho \lambda(t-2, t-1)}{(1-\rho) \lambda+\rho \lambda(t-2, t-1)+\sigma \eta(t)} P(t-1) .
\end{aligned}
$$

\footnotetext{
${ }^{23}$ See Appendix A for more detail on the size of such a shock where the ZLB threatens to bind.
} 
This monetary policy rule is assumed to be completely credible $\forall t$. This rule delivers the inflation target of zero on average. Because $\lambda^{r}(t-1, t)$ appears in the denominator, the price level rule calls for countercyclical price level movements.

We conjecture that a such a price rule (18) restores complete markets consumption allocation even under the incomplete markets contract. To see this consider equation (9) given agents believe that the central bank will credibly follow the countercyclical price rule. The right hand side of the consolidated budget constraint can again be written as $w(t) \sum_{i=0}^{T} e_{i}$, that is, the constraint is linear in $w(t)$. Given the timing protocol of the model, $w(t)$ is known to households at date $t$ when optimization takes place. This means that households solve a non-stochastic problem under the conjecture at date $t$. The set of non-stochastic problems for the $\mathrm{T}+1$ households has a known solution, as shown in the subsection concerning the nonstochastic balanced growth path. This solution indicates that each household consumes $(1 /(T+1)) w(t) \sum_{i=0}^{T} e_{i}$, an "equity share" in the real output of the credit sector of the economy at date $t$. In addition, this solution implies $A(t)=0 \forall t$ and $R^{n}(t, t+1)$ is the rate at which the credit market clears. Intuitively, the monetary authority makes the price level contingent on the state and therefore provides the missing private sector state-contingency under the NSCNC friction. This verifies the conjectured stationary equilibrium. ${ }^{24}$

The cash-using segment of the economy is affected by the countercyclical price level rule (18). In terms of inflation rates, inflation would be relatively high at times when output is growing slowly and inflation would be relatively low when output is growing rapidly. On average, however, the net inflation rate is zero, the same as it would be under the price stability rule. Moreover, since the monetary authority rebates the seigniorage back to even dated cash users, their consumption at date $t$ is $\frac{\gamma T}{2} \lambda^{r}(t-1, t) w(t-1)$, same as the consumption of cash users in non-stochastic case. Note that the the consumption of the cash users is lower than credit users, but like the credit

\footnotetext{
${ }^{24}$ This result for the low $\sigma$ case is similar to Sheedy (2014) and Koenig (2013) in related economies.
} 
users, their consumption is proportional to the income at date $t$.

Another way to view the optimal monetary policy in the low volatility economy is as nominal income targeting. ${ }^{25}$ Nominal GDP, denoted $Y^{n}(t)$, in this model is given by

$$
Y^{n}(t)=P(t) w(t)\left[\frac{T \gamma}{2}+\sum_{i=0}^{T} e_{i}\right] .
$$

The target nominal GDP at date $t$, assuming $P(0)=w(0)=1$ simplifies to

$$
Y^{n, \star}(t)=\lambda^{t}\left[\frac{T \gamma}{2}+\sum_{i=0}^{T} e_{i}\right]
$$

and in particular, the target at date $t+1$ can be written as

$$
Y^{n, \star}(t+1)=\lambda P(t) w(t)\left[\frac{T \gamma}{2}+\sum_{i=0}^{T} e_{i}\right] .
$$

Consider (19) at date $t+1$ :

$$
\begin{aligned}
Y^{n}(t+1) & =P(t+1) w(t+1)\left[\frac{T \gamma}{2}+\sum_{i=0}^{T} e_{i}\right] \\
& =\frac{(1-\rho) \lambda+\rho \lambda(t-1, t)}{(1-\rho) \lambda+\rho \lambda(t-1, t)+\sigma \eta(t+1)} P(t) \lambda^{r}(t, t+1) w(t)\left[\frac{T \gamma}{2}+\sum_{i=0}^{T} e_{i}\right] \\
& =[(1-\rho) \lambda+\rho \lambda(t-1, t)] P(t) w(t)\left[\frac{T \gamma}{2}+\sum_{i=0}^{T} e_{i}\right] .
\end{aligned}
$$

Comparison of (21) and (24) indicates that the monetary policy would return nominal GDP exactly to the target nominal GDP path each period provided $\rho=0$, that is, in the case of no serial correlation. When shocks are

\footnotetext{
${ }^{25}$ For an extensive discussion of interpretations of monetary policiies in this class as nominal income targeting, see Sheedy (2014).
} 
serially correlated, the policy returns nominal GDP partially toward target depending on the value of $\rho .^{26}$

Note that in this economy if the central bank followed alternative policy rules such as the fixed currency stock rule or the price stability rule, it will not be able to achieve one or both of it's objectives. For example, following the fixed currency stock rule, the average inflation will be negative instead of zero. In the case of the price stability rule, the gross real interest rate $R(t, t+1)$ is always equal to the expected gross rate of wage growth $E_{t}[\lambda(t, t+1)]$. As a result such a price rule does not restore the first best consumption allocation among the credit market participants.

\section{Zero lower bound}

In this section we first construct an example economy to illustrate how the credit markets are disrupted when the central bank allows the gross nominal interest rate to be negative. In this economy since the the expected real rate of return on money is higher than the growth rate of productivity, credit market participants, savers in particular, will no longer wish to hold the privately-issued paper of the younger agents. ${ }^{27}$ Instead, they will want to hold currency issued by the government. In such an equilibrium, risk sharing between agents at any date breaks down and agents do not consume the equity share consumption allocation discussed in sections 3 and 4 . This motivates our policy intervention discussed in section 5.2

\footnotetext{
${ }^{26}$ We note that this model is unlikely to fit macroeconomic data from recent decades, since the monetary policy supporting the stationary equilibrium here has not been the one in use in the largest economies in recent years. Central banks around the world have mostly adopted policies emphasizing stable prices. The historically-observed price stability policy is inappropriate in the economy studied in this paper.

${ }^{27}$ This kind of household debt is estimated by Mian and Sufi (2011) as approximately \$20-25 trillion in today's dollars. We think of this as a large amount of asset holding by relatively older participant households that could become a demand for currency.
} 


\subsection{An example economy}

Consider the stochastic model described in section 2. However, assume that at each date $t$, the monetary policymaker moves after nature and chooses $P(t)$ such that

$$
P(t)=\frac{\delta}{\lambda^{r}(t-1, t)} P(t-1)
$$

where $0<\delta<1$. This deflationary monetary policy rule is assumed to be completely credible $\forall t$. In this economy therefore, the expected real of return on money is higher than the growth rate of the economy. As a result, credit market participants, in particular the savers in the life-cycle model, want to hold money. The total asset market clearing condition is now given by

$$
\frac{\sum_{j=0}^{T-1} a_{t-j}(t)}{P(t)}+h^{d}(t)=h(t) .
$$

We conjecture that in this economy credit market participants are strictly worse off relative to the economy where the price rule restores complete markets consumption allocation even under NSCNC. In equilibrium, since the real return on debt equals the return on money, the right hand side of the consolidated budget constraint can again be written as $w(t) \sum_{i=0}^{T} e_{i} \delta^{i}$. Therefore the first period consumption in this economy is

$$
c_{t}(t)=\frac{1}{T+1} w(t) \sum_{i=0}^{T} e_{i} \delta^{i} .
$$

In general, the optimal consumption of different cohorts at date $t$ is

$$
c_{t-j}(t)=\frac{1}{\delta^{j}} \frac{1}{T+1} w(t) \sum_{i=0}^{T} e_{i} \delta^{i}
$$

Since $\delta<1$, the first period consumption in this economy is lower than the complete market benchmark. From equation (28), it is obvious that the risk sharing breaks down in this economy. ${ }^{28}$ This motivates the following

\footnotetext{
${ }^{28}$ Note that since the real rate of return on debt is higher than the growth rate of productivity, the life-cycle consumption profile is upward sloping and the slope is higher relative to the complete markets benchmark. However, if lump sum taxes on the credit users finance this deflation, welfare is strictly lower in this economy.
} 
subsection where policy intervention ensures that the rate of return on private credit dominates the rate of return on currency.

\subsection{Policy when the ZLB threatens}

When a relatively large negative shock $\eta(t)$ is drawn by nature in this economy, consumption in the current period will fall. This, by itself, is not a concern for the equilibria we have described. However, if the serial correlation of productivity shocks is high enough, future consumption growth may also be expected to be negative. The zero lower bound is encountered when, given the price rule in equation (18), expected net consumption growth is negative, as can be seen from equation (10) which pins down the nominal interest rate.

In this scenario, the central bank announces that if a large negative shock hits the economy at any date $t$ such that the agents would otherwise expect nominal interest rate $R^{n}(t, t+1)<1$, the central bank will react by credibly promising to create a higher than usual price level at date $t+1$ such that the zero lower bound condition on the net nominal interest rate does not bind. The policy rule therefore can be described as

$$
P(t+1)=\left\{\begin{array}{ccc}
\frac{E_{t}[\lambda(t, t+1)]}{\lambda^{r}(t, t+1)} P(t) & \text { if } & E_{t}[\lambda(t, t+1)]>1, \\
\frac{E_{t}[\lambda(t, t+1)]\left[1+\vartheta_{p}(t+1)\right]}{\lambda^{r}(t, t+1)} P(t) & \text { if } & E_{t}[\lambda(t, t+1)] \leq 1,
\end{array}\right.
$$

where $\vartheta_{p}(t+1)>0$ is such that $E_{t}[\lambda(t, t+1)] \vartheta_{p}(t+1)=1^{+}$, and $1^{+}$represents a value just larger than unity. The top branch of (29) is just the complete markets monetary policy rule (18) of the previous section. Therefore, (29) can be understood as a generalized version of the policy rule proposed there. The generalization is simply the value of $\vartheta_{p}(t+1)$.

We conjecture that a complete markets allocation exists even under the incomplete markets contract, provided the policymaker follows the complete markets policy rule (29). Consideration of equation (9) indicates that, under this conjecture and given the complete markets policy rule, the right hand side of the consolidated budget constraint can again be written as 
$w(t) \sum_{i=0}^{T} e_{i}$, that is, the constraint is linear in $w(t)$. Given the timing protocol of the model, $w(t)$ is known to households at date $t$ when optimization takes place. This means that households solve a non-stochastic problem under the conjecture at date $t$. This solution indicates that each household consumes $(1 / T+1) w(t) \sum_{i=0}^{T} e_{i}$, an "equity share" in the real output of the credit sector of the economy at date $t$. In addition, this solution implies $A(t)=0 \forall t$ and this verifies the conjectured stationary equilibrium.

The policy rule (29) maintains complete markets allocations for participant households and does not alter the consumption of cash users. The even dated consumers still consume $\frac{\gamma T}{2} \lambda^{r}(t-1, t) w(t-1)$.

\section{Conclusions}

This model has some ability to address core issues concerning recent monetary policy, which, because of the financial crisis of 2007-2009, has become more focused on private credit market behavior. The model has substantial income and wealth inequality, which gives rise to a large and active credit market with some realistic features, including relatively young households wishing to pull consumption forward in the life cycle, relatively old households saving for the later stages of life, and cash-using households that are precluded from the credit market. The net nominal interest rate is positive at all times, which keeps credit market households from wishing to hold cash. A relatively large and persistent negative aggregate shock (that is, a big recession) means that this nominal interest rate can sometimes encounter the zero lower bound. We have made assumptions that make the analysis particularly simple and tractable, despite the relatively substantial heterogeneity of households and the existence of an aggregate shock to the pace of growth.

The key friction in the model is non-state contingent nominal contracting (NSCNC) in the credit sector. The non-state contingency means that credit market equilibrium will feature inefficient risk sharing if there is no intervention. In this model, the implications of this inefficiency could be substantialas an extreme example, if the credit market broke down completely so that 
all participant households only consume based on income today, then some households would be unable to consume at all, and a population-weighted social welfare function would tend toward negative infinity. However, the fact that the contracting is in nominal terms means that the monetary authority may be able to replace the missing state-contingency with appropriate price level movements. This is in fact what happens in the stationary equilibria we study, and this constitutes optimal monetary policy provided the policymaker is focused first on the performance of the relatively large credit market, and only secondarily on maintaining an exogenously-given inflation target on average. The required price level movements are counter-cyclicalmeaning that relatively high inflation would be associated with low growth, and relatively low inflation would be associated with high growth, in such a way that the long run average rate of inflation would be unchanged from what it would be under ordinary inflation targeting. The required volatility of inflation would be the same as the volatility of the output growth rate.

For some outsized and persistent shocks to real output growth under such a policy, the implied expected consumption growth rate may cause the zero lower bound on the nominal interest rate to be encountered. What is the policymaker to do in this circumstance, if the objective is to maintain smoothly operating credit markets?

We showed that the monetary authority can still maintain complete markets in this circumstance. This intervention can be implemented via a special price level increase. This keeps the nominal interest rate positive and maintains the complete market allocations for credit market participant households. We think these results may help to inform the debate on monetary policy at the zero lower bound. Since the policy implications appear to be quite different, a fruitful area for future research may be to try to better understand whether sticky prices or NSCNC is the more relevant friction for policymakers in this situation. 


\section{References}

[1] Alvarez, F., R. Lucas, and W. Weber. 2001. "Interest rates and inflation." American Economic Review Papers and Proceedings, May, pp. 219-225.

[2] Araujo, A., S. Schommer, and M. Woodford. 2015. "Conventional and unconventional monetary policy with endogenous collateral constraints." American Economic Journal: Macroeconomics, forthcoming.

[3] Azariadis, C., J. Bullard, and B. Smith. 2001. "Public and private circulating liabilities." Journal of Economic Theory 99(1/2): 59-116.

[4] Berentsen, A., G. Camera, and C. Waller. 2007. "Money, credit, and banking." Journal of Economic Theory 135(1): 171-195.

[5] Bohn, H. 1988. "Why do we have nominal government debt?" Journal of Monetary Economics 21(1): 127-140.

[6] Bullard, J. 2014. "Discussion of 'Debt and incomplete financial markets' by Kevin Sheedy." Brookings Papers on Economic Activity, Spring, pp. 362-368.

[7] Bullard, J., and B.D. Smith. 2003a. "Intermediaries and payments instruments." Journal of Economic Theory 192(2): 172-197.

[8] Bullard, J. and B.D. Smith. 2003b. "The value of inside and outside money." Journal of Monetary Economics 50(2): 389-417.

[9] Buera, F., and J. P. Nicolini. 2015. "Liquidity Traps and Monetary Policy: Managing a Credit Crunch." Working paper \# 714, Federal Reserve Bank of Minneapolis.

[10] Burhouse, S., and Y. Osaki. 2012. "2011 FDIC National Survey of Unbanked and Underbanked Households." U.S. Federal Deposit Insurance Corporation, September. 
[11] Cecchetti, S., M.S. Mohanty, and F. Zampolli. 2011. "The real effects of debt." Working paper \#352, September. Presented at the Jackson Hole Symposium, August 2011.

[12] Chari, V., L. Christiano, and P. Kehoe. 1991. "Optimal fiscal and monetary policy: some recent results." Journal of Money, Credit, and Banking 23(3(2)): 519-539.

[13] Chari, V., and P. Kehoe. 1999. "Optimal fiscal and monetary policy." In J. Taylor and M. Woodford, eds., Handbook of Monetary Economics, Volume 1C, 26: 1671-1745. Elsevier.

[14] Cole, S. 2015. "Learning and the effectiveness of central bank forward guidance." Working paper, UC-Irvine.

[15] Curdia, V., and M. Woodford. 2010. "Conventional and unconventional monetary policy." Federal Reserve Bank of St. Louis Review 92(4): 229264.

[16] Curdia, V., and M. Woodford. 2011. "The central bank balance sheet as an instrument of monetary policy." Journal of Monetary Economics.

[17] D'Amico, S., and T. King. 2011. "Flow and stock effects of large-scale Treasury purchases." Working paper, Federal Reserve Board.

[18] Diamond, P. 1965. "National debt in a neoclassical growth model." American Economic Review 55(5): 1126-1150.

[19] Doepke, M., and M. Schneider. 2006. "Inflation and the redistribution of nominal wealth." Journal of Political Economy 114(6): 1069-1097.

[20] Eggertsson, G., and N. Mehrotra. 2014. "A model of secular stagnation." NBER Working Paper \#20574, October.

[21] Eggertsson, G. and M. Woodford. 2006. "Optimal monetary and fiscal policy in a liquidity trap." NBER Chapters, in: NBER International Seminar on Macroeconomics 2004, pp 75-144 
[22] Fildardo, A., and B. Hofmann. 2014. "Forward guidance at the zero lower bound." Bank of International Settlements Quarterly Review, March, pp. 37-53.

[23] Gagnon, J., M. Raskin, J. Remache, and B. Sack. 2011. "Large-scale asset purchases by the Federal Reserve: Did they work?" Federal Reserve Bank of New York Economic Policy Review, May, 41-59.

[24] Garriga, C., F. Kydland, and R. Sustek. 2015. "Mortgages and monetary policy." Working paper \#2013-037A, Federal Reserve Bank of St. Louis.

[25] Gertler, M., and P. Karadi. 2010. "A model of unconventional monetary policy." Journal of Monetary Economics 58: 17-34.

[26] Glover, A., J. Heathcote, D. Krueger, and J.V. Ríos-Rull. 2011. "Intergenerational redistribution in the great recession." NBER Working Paper \#16924.

[27] Gomis-Porqueras, P. and A. Haro. 2009. "A geometric description of a macroeconomic model with a center manifold." Journal of Economic Dynamics and Control 33: 1217-1235.

[28] Hamilton, J., and C. Wu. 2012. "The effectiveness of alternative monetary policy tools in a zero lower bound environment." Journal of Money, Credit, and Banking 44: 3-46.

[29] Joyce, M., A. Lasaosa, I. Stevens, M. Tong. 2010. "The financial market impact of quantitative easing." Bank of England working paper \#393.

[30] Koenig, E. 2013. "Like a good neighbor: Monetary policy, financial stability, and the distribution of risk." International Journal of Central Banking 9: 57-82.

[31] Krishnamurthy, A., and A. Vissing-Jorgensen. 2011. "The effects of quantitative easing on interest rates: Channels and implications for policy." Brookings Papers on Economic Activity 2: 216-235. 
[32] Lagos, R., and R. Wright. 2005. "A unified framework for monetary theory and policy analysis." Journal of Political Economy 113: 463-484.

[33] Levin, A., D. Lopez-Salido, E. Nelson, and Tack Yun. 2010. "Limitations on the effectiveness of forward guidance at the zero lower bound." International Journal of Central Banking, 6(1): 143-189.

[34] Mian, A., and A. Sufi. 2011. "House prices, home equity-based borrowing, and the U.S. household leverage crisis." American Economic Review 101: 2132-2156.

[35] Neely, C. 2015. "Unconventional monetary policy had large international effects." Journal of Banking and Finance, 52: 101-111.

[36] Sanches, D., and S. Williamson. 2010. "Money and credit with limited commitment and theft." Journal of Economic Theory 145: 1525-1549.

[37] Schmitt-Grohe, S., and M. Uribe. 2004. "Optimal fiscal and monetary policy under sticky prices." Journal of Economic Theory 114: 198-230.

[38] Sheedy, K. 2014. "Debt and incomplete financial markets: A case for nominal GDP targeting." Brookings Papers on Economic Activity, Spring: 301-361.

[39] Siu, H. 2004. "Optimal fiscal and monetary policy with sticky prices." Journal of Monetary Economics 51: 575-607.

[40] Rocheteau, G., and R. Wright. 2005. "Money in search equilibrium, in competitive equilibrium, and in competitive search equilibrium." Econometrica 73: 175-2002.

[41] Wallace, N. 1981. "A Modigliani-Miller theorem for open-market operations." American Economic Review 71: 267-274.

[42] Werning, I. 2014. "Discussion of 'Debt and incomplete financial markets' by Kevin Sheedy." Brookings Papers on Economic Activity, Spring, pp. 368-373. 
[43] Williamson, S. 2012. "Liquidity, monetary policy, and the financial crisis: A new monetarist approach." American Economic Review 102: 25702605.

[44] Williamson, S. 2015. "Scarce collateral, the term premium, and quantitative easing." Journal of Economic Theory, forthcoming.

[45] Woodford, M. 2012. "Methods of policy accommodation at the interestrate lower bound." Presented at the Jackson Hole Symposium, August.

[46] Zervou, A. 2013. "Financial market segmentation, stock market volatility and the role of monetary policy." European Economic Review 63: 256-272.

\section{A Size of a large productivity shock}

Consider an economy which is the steady-state at date $t-1$ such that

$$
\lambda(t-2, t-1)=\lambda .
$$

For the agents in this economy to expect that the economy may be at the ZLB at date $t+1$, it must be that $E_{t} \lambda(t, t+1) \leq 1$. From equation (2), we know that $E_{t} \lambda(t, t+1)$ is given by

$$
E_{t} \lambda(t, t+1)=(1-\rho) \lambda+\rho \lambda(t-1, t) .
$$

Therefore, the productivity growth between periods $t-1$ and $t$, i.e. $\lambda(t-$ $1, t) \leq \frac{1-(1-\rho) \lambda}{\rho}$.

We also know that $\lambda(t-1, t)$ is given by the following relationship

$$
\begin{aligned}
& \lambda(t-1, t)=(1-\rho) \lambda+\rho \lambda(t-2, t-1)+\sigma \eta(t) \quad \\
&=\lambda+\sigma \eta(t)
\end{aligned}
$$

Therefore, the size of the shock at date $t$ such that the agents expect the ZLB to bind at date $t+1$ is given below

$$
\eta(t) \leq \frac{1-\lambda}{\sigma \rho}
$$

